\title{
Flow cytometry as a valuable tool to study cyanobacteria: A mini-review
}

\author{
Barbara Poniedziałek $^{{ }^{*}}$, Halina I. Falfushynska ${ }^{2}$, Piotr Rzymski ${ }^{1}$ \\ ${ }^{1}$ Department of Environmental Medicine, Poznan University of Medical Sciences, Rokietnicka 8, 60-806 Poznań, Poland, \\ e-mail: bpon@ump.edu.pl (*corresponding author),rzymskipiotr@ump.edu.pl \\ ${ }^{2}$ Research Laboratory of Comparative Biochemistry and Molecular Biology, Department of Health Care, Physical Rehabilitation and Vital \\ Activity Safety, Ternopil V. Hnatiuk National Pedagogical University, M. Kryvonosa 2, 46027 Ternopil, Ukraine, e-mail: halynka.f@gmail. \\ com, falfushynska@tnpu.edu.ua

\begin{abstract}
Flow cytometry (FCM) is routinely used in medical and veterinary diagnostics although it is also widely applied in environmental studies, including phytoplankton investigations. Cyanobacteria are wide-spread photosynthetic microorganisms that attract attention due to their ecology and potential toxicity. Therefore, novel research tools are being applied in their investigation. This paper characterizes FCM as a technique that enables photopigments (chlorophylls and phycocyanin) expressed by cyanobacteria to be excited and their emission to be subsequently detected. This feature not only allows cells to be counted in a rapid manner but also enables a wide range of potential applications in ecological and biochemical studies. The main advantages of FCM, such as rapid, automatic and precise measurements requiring small sample volumes, are also discussed in this paper along with challenges including analyses of filamentous cyanobacteria and signal overlapping. It is expected that FCM will continue to be used in some fields of cyanobacterial studies.
\end{abstract}

Key words: flow cytometry, cyanobacteria, fluorescence, chlorophyll, phycocyanin

\section{Introduction}

Cyanobacteria are a common component of the phytoplankton community responsible for primary production in aquatic environments, both freshwater and marine. Terrestrial forms of these microorganisms have also been widely recognized (Cavalier-Smith 2002; Oren 2010) and recently, their contribution to human microbiom has been revealed (Karczewski et al. 2014). Cyanobacteria are considered to be the earliest living forms on earth with fossil evidence dating back over 3.5 billion years. Long-term evolution triggered various adaptations and mechanisms that allowed them to occupy nearly every possible type of environment in all geographical latitudes (Bold 1985). Cyanobacteria can not only survive, but thrive in extremely different conditions and environments including those considered to be almost uninhabitable and highly polluted. A broad range of adaptive mechanisms allowed certain species to tolerate high temperatures, low humidity, high or low nutrient concentrations and increased levels of pollution, and to successfully compete with sympatric organisms (Whitton and Potts 2000; Seckbach 2007; Rzymski and Poniedziałek 2014a). Loading of nutrients (particularly inorganic forms of nitrogen and phosphorus), sunny, calm weather and slightly alkaline $\mathrm{pH}$ stimulate cyanobacteria growth to high densities, resulting in the formation of surface blooms in lakes, slow flowing rivers and coastal areas (Rzymski and Poniedziałek 2014b). In the Baltic Sea blooms of nitrogen-fixing species such as Nodularia spumigena and Aphanizomenon flos-aquae can be observed almost uninterruptedly during summer months and may encompass up to $100000 \mathrm{~km}^{2}$ (Öberg 2016). Cyanobacterial blooms are usually manifested by blue-green foam, scum, or mats floating on the water surface. In temperate zones such events are usually observed during summer and early autumn (Mowe et al. 2015), and over the decades this has raised concerns because of the ability of certain species and strains to produce toxic metabolites. These molecules belong to various chemical classes such as cyclic peptides (e.g. microcystins), alkaloids (e.g. anatoxin-a, saxitoxins), polymethoxy-1-alkenes, macrolides or non-essential amino acids (e.g. BMAA) 
(Poniedziałek et al. 2012; Rzymski et al. 2017a,b), and some are yet to be identified (Poniedziałek et al. 2015; Rzymski et al. 2017b). Some cyanobacterial species, e.g. Arthrospira platensis, can be used in the production of food (Rzymski et al. 2015; Rzymski and Jaśkiewicz 2017), some others are being investigated as a potential source of biofuels, anitbiotics and anticancer drugs (Costa et al. 2012; Silva-Stenico et al. 2013; Johnson et al. 2016). Altogether, the ecology, biochemistry, toxicity and application of cyanobacteria is the subject of numerous studies that often employ various, interdisciplinary methods.

In this mini-review we characterize flow cytometry (FCM) as a potential research method that can be applied to study cyanobacteria. FCM is routinely applied in biomedical science as it identifies cell populations based on their light scatter, and detects fluorescence signals emitted by synthetic molecules used to dye cellular components for various purposes. However, apart from its use in medical diagnostics (e.g. in hematology, transplantation, tumor immunology and chemotherapy, prenatal diagnosis and genetics), FCM has also become increasingly important in other fields, such as those dealing with microbial pollution of drinking water (Hammes and Egli 2010; Liu et al. 2016) or honey bee reproduction (Rzymski et al. 2012). Moreover, photosynthetic pigments can be easily excited using FCM and their fluorescence signal subsequently recorded. Thus, FCM has already been successfully applied in different studies of phytoplankton. Considering the multifaceted importance of cyanobacteria, FCM may serve as a valuable tool for expanding the scope of investigations focusing on these microorganisms.

\section{General introduction to flow cytometry}

The origins of FCM date back to the late 1960s, when, in 1969, Wolfgang Gohde at the University of Munster patented the first device using fluorescence cytometry (ICP 11), later put on the market by the German company Phywe AG. In the 1970s, an American company, Bio/Physics Systems engaged in the design of these devices. In subsequent decades the development of the laser and optical engineering, electronics and computer science helped to improve the capabilities of flow cytometers and simplified their use (Baran 2008). Currently, the major producers in this field include Beckman Coulter, Becton-Dickinson, Thermo Fisher Scientific, and DakoCytomation. These manufacturers provide a number of devices equipped with a variety of lasers with different wavelengths of light that allow to study cells stream flowing at a speed of over 100 000 cells per second (Melamed et al. 1990). Currently,
FCM is routinely used in medical and veterinary diagnostics, and it is a well-established method in hematology, transplantology, tumor immunology and chemotherapy, prenatal diagnostics and genetics (Kaczmarek 2002; Poniedziałek et al. 2014). A PubMed search query using the MeSH term "flow cytometry" returns nearly 180,000 papers published between 1979 and 2016 with over $50 \%$ published in only the last 15 years. FCM is also gaining popularity in environmental sciences and is being applied in various phytoplankton and bacterial analyses (Dubelaar and Jonker 2000; Vives-Rego et al. 2000; Karo et al. 2008; Rzymski et al. 2014a).

FCM is a method for conducting a multi-parameter analysis of cells suspended in liquid and passing through a laser beam. As cells pass through the flow chamber they are hit with a beam which is then scattered in different directions and recorded as forward light scatter (FSC) and side light scatter (SSC). Simultaneously, cells can also be excited with the light of a given wavelength and their fluorescence can be measured. However, in order to detect any fluorescence, suspended cells usually require staining with organic dyes of heterocyclic structure, prior to FCM analyses, although certain cells, such as those of photosynthetic organisms, contain natural fluorochromes whose fluorescence signals can be successfully measured using FCM. It should, however, be highlighted that the presence of these molecules limits the possibility to stain cells with synthetic dyes as excitation and emission spectra can greatly overlap (Davis 2007). In particular cases an overlap in dye emission spectra and their interference with the autofluorescence of cell components can be estimated (Tashyreva et al. 2013). Thus, attention should be paid to the choice of appropriate fluorescent dyes with respect to the particular phytoplankton and microorganism strain being analyzed and the available lasers with which the FCM instrument is equipped (Karo et al. 2008).

Most FCM devices are equipped with an air-cooled argon ion laser that emits $\lambda=488 \mathrm{~nm}$ light detecting three-color fluorescence in channels FL1 (515-545 $\mathrm{nm})$, FL2 (554-606 nm) and FL3 (>670 nm). Modern flow cytometers can also feature a green laser $(\lambda=532$ $\mathrm{nm})$, a red diode laser $(\lambda=635 \mathrm{~nm})$, a UV diode $(\lambda=$ $365 \mathrm{~nm}$ ) and allow fluorescence to be measured in the FL-4 and FL-5 channel. The use of FSC and SSC combined with a fluorescence measurement can be applied for phytoplankton sorting and distinguishing systematic groups in examined water samples (Phinney and Cucci 1989) as well as other analyses based on fluorescence pigments or dyes. As shown by Olson et al. 1985, marine phytoplankton distributions can be successfully measured using shipboard FCM. More recently, an FCM protocol for quantitative and rapid analysis of 
Microcystis cells and colonies in lake sediment was de-

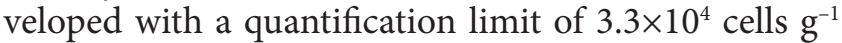
dry weight (dw) (Zhou et al. 2012).

Various FCM instruments are also coupled with cell sorters. In this case, individual cells can be diverted from the fluid stream based on entities such as cell morphology, taxonomic position, surface and intracellular protein expression, gene expression, and cellular physiology, and collected into homogenous fractions for further analyses (Ibrahim and van den Engh 2007). It should, however, be stressed that various phytoplankton cells may survive such a process at varying viability, particularly if it is applied to fragile groups such as dinoflagellates Karenia brevis (Sinigalliano et al. 2009). Nevertheless, FCM featuring a sorting device has been successfully applied to isolate different phytoplankton taxa (including green algae, diatom, cryptomonads and cyanobacteria) from mixed cultures at a success rate of $80 \%$ (Cellamare et al. 2010). The use of such devices may decrease the time necessary to separate different phytoplankton groups from water samples for further analyses (e.g. chemical, biochemical, molecular). One should stress that some groups of phytoplantkon may be difficult to distinguish and isolate using this technique, e.g. colonial forms and filamentous species of cyanobacteria, as individualised cells might be challenging to obtain. However, if analyses on viable and intact cells are not necessary, the trichomes may be sonicated in different solutions (e.g. Triton-X100) as described by Avezedo et al. (2011).

It is worth noting that FCM has already contributed to the identification of certain cyanobacteria, particularly picocyanobacteria. FCM allowed for the first determination of Prochlorococcus with cell diameter ranging between 0.5 and $0.7 \mu \mathrm{m}$ (Campbell and Nolla 1994). Picocyanobacteria constitute an important fraction of phytoplankton and contribute to aquatic ecosystem function by their high production rate (up to over $95 \%$ of total phytoplankton production) and incorporation of dissolved organic matter into the food web. Compared to microplanktonic cyanobacteria, their picoplanktonic relatives remains a poorly studied fraction of plankton (Jakubowska and Szeląg-Wasielewska 2015). Due to its sensitivity, ability to couple with other analyses or cell sorting, FCM may be particularly useful in future studies of this particular cyanobacterial fraction.

One of the advantages of FCM is the possibility of rapid and automated measurement with only a small volume of the tested samples necessary for investigations. Usually $1 \mathrm{~cm}^{3} 1 \times 10^{6}$ cells in certain volume is sufficient for multiple analysis (e.g. absolute count of cyanobacteria cells coupled with fluorescence detection), the samples can also be diluted if the use of lower volumes if necessary.

\section{Chlorophyll fluorescence measurement}

Cyanobacteria have a supra-molecular structure; photosystem II (PSII); in the thylakoid membrane. The reaction center (RC) complex for initial charge separation is in the center of PS II surrounded laterally by peripheral light-harvesting antenna pigment-protein complexes (Adir 2005; Tomo et al. 2008). They are both located within the same plane of the thylakoid membrane. Phycobilisome, another pigment-protein complex, is attached to PS II (MacColl 2004). It is known that light energy captured by phycobilisome is transferred to light-harvesting protein, and finally to an RC complex. Light energy, which is finally absorbed by chlorophyll molecules of PSII in the cell, and can be used to drive photosynthesis, dissipates as heat or re-emits as fluorescence (Fig. 1; Butler 1978). All of these processes are strongly associated with each other. In photosynthetic cells grown under optimal and undisturbed conditions, relations in the ratio of these processes do not undergo any significant changes, while emission of fluorescence usually does not exceed $0.6-3 \%$ of absorbed light energy (Krause and Weis 1991; Hall and Rao 1999). However, if the efficiency of one of the above processes is disturbed it will be reflected in respective changes of their ratios (Murata et al. 2007).

Damage to PSII is usually the first manifestation of the cell's reaction to environmental stress and leads to inhibition of all light-dependent reactions (Garstka 2007; Murata 2007). Therefore, measurement of chlorophyll fluorescence can provide information on the changes in the efficiency of the photosynthesis apparatus (Maxwell and Johnson 2000). Indirectly, it can impart information on the cell's condition and growth state.

Chlorophyll fluorescence occurs in the red region of visible light, between 675 and $685 \mathrm{~nm}$ (Lichtenthaler

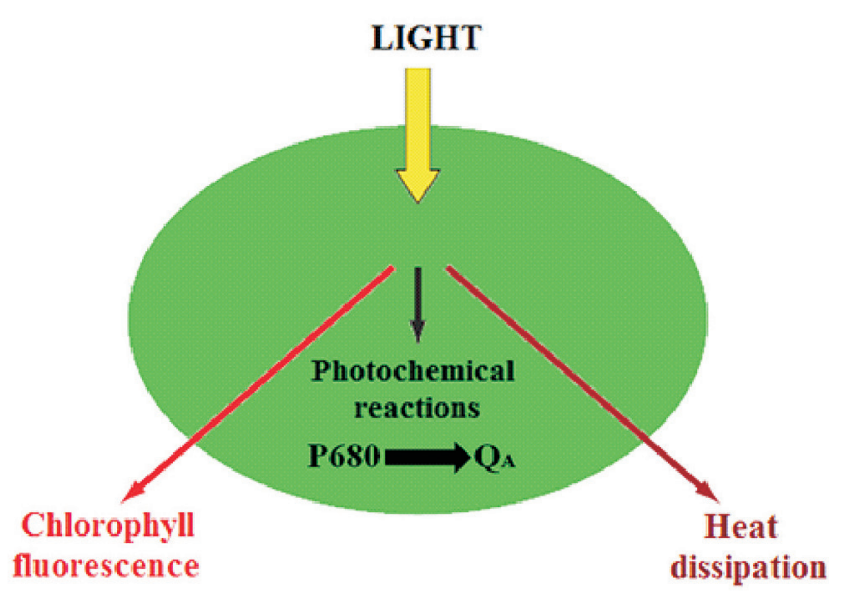

Fig. 1. Fate of light absorbed by cyanobacterial cell. P680 - Photosystem II primary donor; $\mathrm{Q}_{\mathrm{A}}$ - the first quinone electron acceptor of P680 

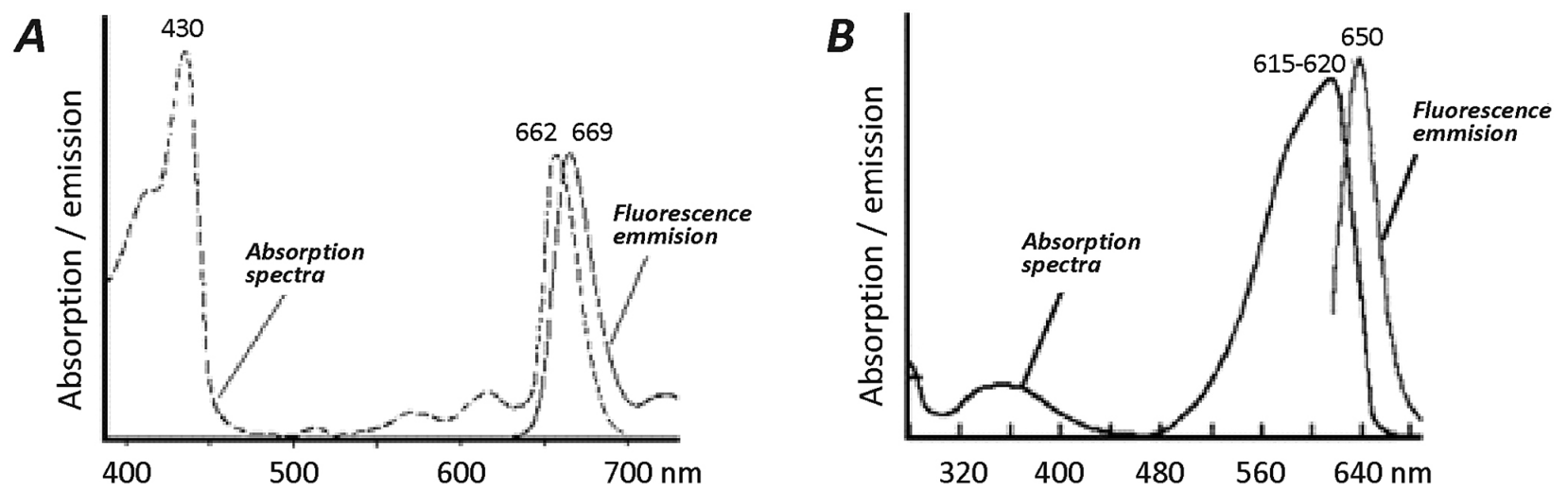

Fig. 2. The absorption and emission spectra of chlorophyll- $a(\mathrm{~A})$ and phycocyanin- $c$ (B)

1988; Fig. 2). Therefore, FCM allows the measurement of cyanobacterial chlorophyll $a$ in the FL-3 channel (> $670 \mathrm{~nm})$.

Adaptation of the FCM technique for measurement of chlorophyll fluorescence can be used to test the impact of different factors on cyanobacteria development i.e. $\mathrm{pH}$, toxic metals, herbicides and other pollutants, under controlled laboratory conditions (Readman et al. 2004; Poniedzialek et al. 2011; Dudkowiak et al. 2011; Rzymski et al. 2014b). Changes in emission constitute a response of cells to environmental stress. If PSII is damaged (i.e. due to a high uptake of toxic substances) inhibition of fluorescence will be observed in flow cytometric analyses, and most likely its photosynthetic activity will be disturbed (Krause and Weis 1991). Cells tolerant to environmental stress will not undergo fluorescence change or they may enhance fluorescence values. Although chlorophyll fluorescence emission does not provide an understanding of the exact mechanisms of toxicity, FCM is an interesting technique that could be complimentary to already established assays such as pulse-amplitude modulation (PAM) or delayed fluorescence (Leunert et al. 2013; Acuña et al. 2016), and could provide an effective tool for preliminary selection of species tolerant to diverse environmental stress.

\section{Phycocyanin fluorescence measurement}

Phycocyanin is a pigment-protein complex derived from the light-harvesting phycobiliprotein family present in all species of cyanobacteria and in marine eukaryotic red algae. The C-phycocyanin variant is the dominant accessory pigment in blue-green algae accompanied with allophycyanin and allophycocyanin-B, while the R-phycocyanin variant is found in red-green algae (Glazer 1994; Jordan et al. 2001). When excited with the red laser cyanobacterial phycocyanin emits far red light ( $\geq 650 \mathrm{~nm}$ ) (Fig. 2).

Since phycocyanin pigment-protein complexes participate in transferring signals, its fluorescence emission can be used in environmental stress studies, similar to those based on chlorophyll- $a$ measurement and described above. Moreover, because this pigment is specific to cyanobacteria in phytoplankton formation it could be used in the detection of their presence in water samples. Because cyanobacteria are known to form harmful algae blooms and can pose a threat to human health, a routine and high-frequency monitoring of water bodies, particularly those used for recreational reasons, is necessary. Methods based on chlorophylla concentration measurement and cyanobacterial cell density are regularly employed as dual criteria for determinations of the alert level for cyanobacterial bloom (Ahn et al. 2007). However, the determination of cyanobacterial counts is difficult while chlorophyll-a is also present in other phytoplankton cells. Therefore, phycocyanin- $c$ fluorescence measurement in water samples might be applied for monitoring cyanobacterial development in the environment. In vivo methods include spectrophotometric or fluorometric techniques (Izydorczyk and Tarczyńska 2005; Brient et al. 2008). Although fluorescence emission does not give any information on the concentration of phycocyanin in the water, flow cytometry could be adapted to provide an early cyanobacterial warning system (Dziallas et al. 2011). There are several reports that highlight this possibility (Becker 2002; Dennis 2011). Higher cyanobacterial cell concentration will result in elevated values of fluorescence emission (Sode et al. 1991). In combination with mRNA-RING-FISH, FCM can not only be used to monitor cyanobacterial abundance but also to quantify toxin gene expression (Dziallas et al. 2011).

\section{Conclusion}

FCM is an automatic, time-saving and precise method which requires small quantities of tested samples. Once coupled with cell sorting, it can be successfully applied to isolate cyanobacteria from mixed phytoplankton samples. It also allows the monitoring of $\mathrm{cy}$ - 
anobacterial abundance in water, a useful feature in early detection systems. Considering that FCM equipped with a dual-laser is able to measure chlorophyll-a and phycocyanin, this method could also be of value in ecological studies of cyanobacteria. However, the presence of autofluorescence in cyanobacterial cells limits the use of other assays that employ FCM (and staining cells with synthetic fluorochromes) due to signal overlap. Moreover, filamentous cyanobacteria are rather difficult to study using FCM due to their different trichome lengths, and light scattering does not allow individual cells to be distinguished if not preceded by appropriate trichome sonication. Nevertheless, it is expected that FCM will continue to attract attention in future studies, particularly of picocyanobacteria.

\section{References}

Acuña A.M., Snellenburg J.J., Gwizdala M., Kirilovsky D., van Grondelle R., van Stokkum IH., 2016, Resolving the contribution of the uncoupled phycobilisomes to cyanobacterial pulse-amplitude modulated (PAM) fluorometry signals, Photosynth. Res. 127(1): 91-102.

Adir N., 2005, Elucidation of the molecular structures of components of the phycobilisome: reconstructing a giant, Photosynth. Res. 85(1): 15-32.

Ahn C.Y., Joung S.H., Yoon S.K., Oh H.M., 2007, Alternative alert system for cyanobacterial bloom, using phycocyanin as a level determinant, J. Microbiol. 45(2): 98-104.

Apeldoorn M.E., Egmond H.P., Speijers G.J.A., Bakker G.J.I., 2007, Toxins of cyanobacteria, Mol. Nutr. Food Res. 51(1): 7-60.

Azevedo R., Rodriguez E., Figueiredo D., Peixoto F., Santos C., 2012, Methodologies for the study of filamentous cyanobacteria by flow cytometry, Fresenius Environ. Bull. 21(8): 679- 684 .

Baran J., 2008, Nowa epoka cytometrii przepływowej - przewodnik po współczesnych cytometrach i ich zastosowanie (New time of flow cytometry - Applications of contemporary cytometers), Post. Biol. Kom. 24(Suppl. 24): 3-15 (in Polish, English summary).

Becker A., Meister A., Wilhelm C., 2002, Flow cytometric discrimination of various phycobilin-containing phytoplankton groups in a hypertrophic reservoir, Cytometry 48(1): 45-57.

Bold H.C, Wynne M.J., 1985, Introduction to the Algae: Structure and Reproduction, Prentice-Hall, New Jersey, 720 pp.

Brient L., Lengronne M., Bertrand E., Rolland D., Sipel A., Steinmann D., Baudin I., Legeas M., Le Rouzic B., Bormans M., 2008, A phycocyanin probe as a tool for monitoring cyanobacteria in freshwater bodies, J. Environ. Monit. 10(2): 248-255.

Butler WL., 1978, Energy distribution in photochemical apparatus of photosynthesis, Ann. Rev. Plant Physiol. 29: 345-378.
Campbell L., Nolla H.A., 1994, The importance of Prochlorococcuus to community structure in the central North Pacific Ocean, Limnol. Oceanogr. 39(4): 954-961.

Cavalier-Smith T., 2002, The neomuran origin of archaebacteria, the negibacterial root of the universal tree and bacterial megaclassification, Int. J. Syst. Evol. Microbiol. 52: 7-76.

Cellamare M., Rolland A., Jacquet S., 2010, Flow cytometry sorting of freshwater phytoplankton, J. Appl. Phycol. 22(1): 87-100.

Costa M., Costa-Rodrigues J., Fernandes M.H., Barros P., Vasconcelos V., Martins R., 2012, Marine cyanobacteria compounds with anticancer properties: a review on the implication of apoptosis, Mar. Drugs 10(10): 2181-2207.

Davis D., 2007, Cell sorting by flow cytometry, [in:] Macey M.G. (ed.), Flow cytometry: principles and applications, Humana Press, New York: 257-276.

Dennis M.A., Landman M., Wood S.A., Hamilton D., 2011, Application of flow cytometry for examining phytoplankton succession in two eutrophic lakes, Water. Sci. Technol. 64(4): 999-1008.

Dubelaar G.B.J., Jonker R.R., 2000, Flow cytometry as a tool for the study of phytoplankton, Sci. Mar. 64(2): 135-156.

Dudkowiak A., Olejarz B., Łukasiewicz J., Sikora J., Wiktorowicz K., 2011, Heavy metals effect on cyanobacteria Synechocystis aquatilis study using absorption, fluorescence, flow cytometry, and photothermal measurement, Int. J. Thermophys 32(4): 762-773.

Dziallas C., Pinnow S., Grossart H-P., 2011, Quantification of toxic and toxin-producing cyanobacterial cells by RING-FISH in combination with flow cytometry, Limnol. Oceanogr. Methods 9(2): 67-73.

Garstka M., 2007, Strukturalne podstawy reakcji świetlnych fotosyntezy (Structural background of photosynthetic light reactions), Post. Biol. Kom. 34(3): 445-476 (in Polish, English summary).

Glazer A.N., 1994, Phycobiliproteins-a family of valuable, widely used fluorophores, J. Appl. Phycol. 6(2): 105-112.

Hall D.O., Rao K.K., 1999, Photosynthesis, Cambridge University Press, Cambridge, 214 pp.

Hammes F., Egli T., 2010, Cytometric methods for measuring bacteria in water: advantages, pitfalls and applications, Anal. Bioanal. Chem. 397(3): 1083-1095.

Ibrahim S.F., van den Engh G., 2007, Flow cytometry and cell sorting, Adv. Biochem. Eng. Biotechnol. 106: 19-39.

Izydorczyk K., Tarczyńska M., 2005, Application of in vivo fluorescence measurement for monitoring of phytoplankton dynamics with a special emphasis on Cyanobacteria], Ecohydrol. Hydrobiol. 5(1): 35-41.

Jakubowska N., Szeląg-Wasielewska E., 2015, Toxic picoplanktonic cyanobacteria - Review, Mar. Drugs. 13(3): $1497-1518$.

Jordan P., Fromme P., Witt H.T., Klukas O., Saenger W., Krauss N., 2001, Three-dimensional structure of cyanobacterial photosystem I at 2.5 resolution, Nature 411(6840): 909-917. 
Kaczmarek A., Mackiewicz A., Leporowska E., Osawa T., 2002, Rola i miejsce cytometrii przepływowej w diagnostyce klinicznej (The role of flow cytometry in clinical diagnosis), Współcz. Onkol. 6(6): 366-373 (in Polish, English summary).

Karczewski J., Poniedziałek B., Adamski Z., Rzymski P., 2014, The effects of the microbiota on the host immune system, Autoimmunity 47(8): 494-504.

Karo O., Wahl A., Nicol S.B., Brachert J., Lambrecht B., Spengler H.P., Nauwelaers F., Schmidt M., Schneider C.K., Müller T.H., Montag T., 2008, Bacteria detection by flow cytometry, Clin. Chem. Lab. Med. 46(7): 947-953.

Krause G.H., Weis E., 1991, Chlorophyll fluorescence and photosynthesis: the basics, Annu. Rev. Plant Physiol. Plant Mol. Biol. 42: 313-349.

Leunert F., Grossart H.P., Gerhardt V., Eckert W., 2013, Toxicant induced changes on delayed fluorescence decay kinetics of cyanobacteria and green algae: a rapid and sensitive biotest, PLoS ONE 8: e63127.

Lichtenthaler H.K., 1988, Applications of chlorophyll fluorescence in photosynthesis research, stress physiology, hydrobiology and remote sensing, Springer, Dordrecht, $366 \mathrm{pp}$.

Liu T., Kong W., Chen N., Zhu J., Wang J., He X., Jin Y., 2016, Bacterial characterization of Beijing drinking water by flow cytometry and MiSeq sequencing of the 16S rRNA gene, Ecol. Evol. 6(4): 923-934.

MacColl R., 2004, Allophycocyanin and energy transfer, Biochim. Biophys. Acta 1657(2-3): 73-81.

Mankiewicz J., Tarczyńska M., Walter Z., Zalewski M., 2003, Natural toxins from Cyanobacteria, Acta Biol. Cracov. Ser. Bot. 45(2): 9-20.

Maxwell K., Johnson G.N., 2000, Chlorophyll fluorescence a practical guide, J. Exp. Bot. 51(345): 659-668.

Melamed M.R., Mullaney P.F., Shapiro H.M., 1990, An historical review of the development of flow cytometers and sorters, [in:] Melamed M.R., Lindmo T., Mendelsohn M.L. (eds), Flow cytometry and sorting, Wiley-Liss, New York: 1-8.

Murata N., Takahashi S., Nishiyama Y., Allakhverdiev S.I., 2007, Photoinhibition of photosystem II under environmental stress, Biochim Biophys Acta 1767(6): 414-421.

Öberg J., 2016, Cyanobacteria blooms in the Baltic Sea. HELCOM Baltic Sea Environment Fact Sheets 2016. Retrieved from http://helcom.fi/baltic-sea-trends/environmentfact-sheets/eutrophication/cyanobacterial-blooms-inthe-baltic-sea [accessed 21 March 2017].

Olson R.J., Vaulot D., Chisholm S.W., 1985, Marine phytoplankton distributions measured using shipboard flow cytometry, Deep-Sea Res. A 32(10): 1273-1128.

Oren A., 2011, Cyanobacterial systematic and nomenclature as featured in the International Bulletin of Bacteriological Nomenclature and Taxonomy / International Journal of Systematic Bacteriology / International Journal of Systematic and Evolutionary Microbiology, Int. J. Syst. Evol. Microbiol. 61: 10-15.
Phinney D.A., Cucci, T.L., 1989, Flow cytometry and phytoplankton, Cytometry 10(5): 511-521.

Poniedziałek B., Rzymski P., Kokociński M., 2012, Cylindrospermopsin: water-linked potential threat to human health in Europe, Environ. Toxicol. Pharmacol. 34(3): 651-660.

Poniedziałek B., Rzymski P., Kokociński M., Burchardt L., Wiktorowicz K., 2011, Zmiany fluorescencji chlorofilu Cylindrospermopsis raciborskii i Aphanizomenon flosaquae pod wpływem soli ołowiu (Changes of Cylindrospermopsis raciborskii and Aphanizomenon flos-aquae chlorophyll fluorescence under the influence of lead), Ochr. Środ. Zas. Nat. 48: 513-519 (in Polish, English summary).

Poniedziałek B., Rzymski P., Karczewski J., 2014, Increased apoptosis of regulatory T cells in Crohn's disease, Hepatogastroenterology 61(130): 382-384.

Readman J.W., Devilla R.A., Tarran G., Llewellyn C.A., Fileman T.W., Easton A., Burkill P.H., Mantoura R.F.C., 2004, Flow cytometry and pigment analyses as tools to investigate the toxicity of herbicides to natural phytoplankton communities, Mar. Environ. Res. 58(2-5): 353-358.

Rzymski P., Brygider A., Kokociński M., 2017a, On the occurrence and toxicity of Cylindrospermopsis raciborskii in Poland, Limnol. Rev. 17(1): 23-29.

Rzymski P., Jaśkiewicz M., 2017, Microalgal food supplements from the perspective of Polish consumers: patterns of use, adverse events, and beneficial effects, J. Appl. Phycol. 29(4): 1841-1850.

Rzymski P., Langowska A., Fliszkiewicz M., Poniedziałek B., Karczewski J., Wiktorowicz K., 2012, Flow cytometry as an estimation tool for honey bee sperm viability, Theriogenology 77(8): 1642-1647.

Rzymski P., Poniedziałek B., Mankiewicz-Boczek J., Faassen E.J., Jurczak T., Gągała-Borowska I., Ballot A., Lürling M., Kokociński M., 2017b, Polyphasic toxicological screening of Cylindrospermopsis raciborskii and Aphanizomenon gracile isolated in Poland, Algal Res. 24: 72-80.

Rzymski P., Poniedziałek B., 2014a, In search of environmental role of cylindrospermopsin: A review on global distribution and ecology of its producers, Wat. Res. 66: 320-327.

Rzymski P., Poniedziałek B., 2014b, Blue-green algae blooms: environmental and health consequences, [in:] Lambert A., Roux C. (eds), Eutrophication. Causes, economic implications and future challenges, Nova Science Publishers, New York: 155-181.

Rzymski P., Poniedziałek B., Kokociński M., Jurczak T., Lipski D., Wiktorowicz K., 2014a, Interspecific allelopathy in cyanobacteria: Cylindrospermopsin and Cylindrospermopsis raciborskii effect on the growth and metabolism of Microcystis aeruginosa, Harmful Algae 35: 1-8.

Rzymski P., Poniedziałek B., Niedzielski P., Tabaczewski P., Wiktorowicz K., 2014b, Cadmium and lead toxicity and bioaccumulation in Microcystis aeruginosa, Front. Environ. Sci. Eng. 8(3): 427-433. 
Rzymski P., Niedzielski P., Kaczmarek N., Jurczak T., Klimaszyk P., 2015, The multidisciplinary approach to safety and toxicity assessment of microalgae-based food supplements following clinical cases of poisoning, Harmful Algae 46: 34-42.

Seckbach J., 2007, Algae and cyanobacteria in extreme environments, Springer, Dordrecht, $811 \mathrm{pp}$.

Silva-Stenico M.E., Kaneno R., Zambuzi F.A., Vaz M.G., Alvarenga D.O., Fiore M.F., 2013, Natural products from cyanobacteria with antimicrobial and antitumor activity, Curr. Pharm. Biotechnol. 14(9): 820-828.

Sinigalliano C.D., Winshell J., Guerrero M.A., Scorzetti G., Fell J.W., Eaton R.W., Brand L., Rein K.S., 2009, Viable cell sorting of dinoflagellates by multiparametric flow cytometry, Phycologia 48(4): 249-257.

Sode K., Horikoshi K., Takeyama H., Nakamura N., Matsunaga T., 1991, On-line monitoring of Marine cyanobacterial cultivation based on phycocyanin fluorescence, J. Biotechnol. 21(3): 209-217.
Tashyreva D., Elster J., Billi D., 2013, A novel staining protocol for multiparameter assessment of cell heterogeneity in Phormidium populations (cyanobacteria) employing fluorescent dyes, PLoS ONE 8: e55283.

Tomo T., Akimoto S., Tsuchiya T., Fukuya M., Tanaka K., Mimuro M., 2008, Isolation and spectral characterization of Photosystem II reaction center from Synechocystis sp. PCC 6803, Photosynth. Res. 98(1-3): 293-302.

Vives-Rego J., Lebaron P., Nebe-von Caron G., 2000, Current and future applications of flow cytometry in aquatic microbiology, FEMS Microbiol. Rev. 24(4): 429-448.

Whitton B.A., Potts M., 2000, The ecology of Cyanobacteria: their diversity in time and space, Academic Publishers, Dordrecht, $632 \mathrm{pp}$.

Zhou Q., Chen W., Zhang H., Peng L., Liu L., Han Z., Wan N., Li L., Song L., 2012, A flow cytometer based protocol for quantitative analysis of bloom-forming cyanobacteria (Microcystis) in lake sediments, J. Environ. Sci. 24(9): 1709-1716. 